\title{
Solitalea koreensis gen. nov., sp. nov. and the reclassification of [Flexibacter] canadensis as Solitalea canadensis comb. nov.
}

Correspondence

Soon-Wo Kwon swkwon@rda.go.kr

\author{
Hang-Yeon Weon, ${ }^{1}$ Byung-Yong Kim, ${ }^{2}$ Chang-Muk Lee, ${ }^{2}$ \\ Seung-Beom Hong, ${ }^{2}$ Young-Ah Jeon, ${ }^{2}$ Bon-Sung $\mathrm{Koo}^{2}$ \\ and Soon-Wo Kwon ${ }^{2}$
}

\author{
${ }^{1}$ Mushroom Research Division, National Institute of Horticultural \& Medicinal Crop, Rural \\ Development Administration (RDA), Suwon 441-707, Republic of Korea \\ ${ }^{2}$ Korean Agricultural Culture Collection (KACC), National Agrobiodiversity Center, National \\ Academy of Agricultural Science, RDA, Suwon 441-707, Republic of Korea
}

The genus Flexibacter was first proposed by Soriano (1945), and many species were reported for isolates that originated from soil and freshwater. Later, several species of the genus Flexibacter were classified into other genera on the basis of phylogenetic and geneotypic data. [Flexibacter] aggregans was reclassified as Flexithrix dorotheae (Hosoya \& Yokota, 2007), [Flexibacter] columnaris as Flavobacterium columnare (Bernardet \& Grimont, 1989), [Flexibacter] psychrophilus as Flavobacterium psychrophilum (Bernardet et al., 1996), [Flexibacter] filiformis as Chitinophaga filiformis (Reichenbach, 1989), [Flexibacter] japonensis as Chitinophaga japonensis (Fujita et al., 1996), [Flexibacter] sancti as Chitinophaga sancti (Kämpfer et al., 2006), [Flexibacter] maritimus as Tenacibaculum maritimum and [Flexibacter] ovolyticus as Tenacibaculum ovolyticum (Suzuki et al.,

The GenBank/EMBL/DDBJ accession number for the $16 \mathrm{~S}$ rRNA gene sequence of strain R2A36- $4^{\top}$ is EU787448.

A transmission electron micrograph of cells of strain R2A36- $4^{\top}$ and a table showing the cellular fatty acid compositions of strain R2A36- ${ }^{T}$ and [Flexibacter] canadensis CIP $104802^{\top}$ are available as supplementary material with the online version of this paper.
2001). However, according to the phylogenetic tree (Nedashkovskaya et al., 2003; Weon et al., 2006; Xie \& Yokota, 2006), some among the remaining species are still in need of taxonomic reconsideration.

A soil sample was collected from greenhouse soil cultivated with cucumber (Cucumis sativus L.) from the Yongin region, Korea. The sample was serially diluted with $0.85 \% \mathrm{NaCl}$ (w/ v) and suitable 10-fold dilutions were plated onto R2A agar (Difco). The plates were incubated at $28{ }^{\circ} \mathrm{C}$ for 4 days and strain R2A36- $4^{\mathrm{T}}$ was subsequently isolated. According to the phylogenetic data, strain $\mathrm{R} 2 \mathrm{~A} 36-4^{\mathrm{T}}$ was closely related to [Flexibacter] canadensis CIP $104802^{\mathrm{T}}$ (Christensen, 1980).

For the phenotypic and genotypic tests, strain R2A36-4 ${ }^{\mathrm{T}}$ was routinely cultivated in R2A medium. Gram reaction, oxidase and catalase reaction and hydrolysis of casein, CMcellulose, DNA, starch, Tween 80 and tyrosine were determined according to the methods of Smibert \& Krieg (1994). Cell morphology was examined by using phasecontrast microscopy (AXIO; Zeiss) and transmission electron microscopy with cells grown for 1 day. For transmission electron microscopy, cells were negatively 
stained with $0.5 \%(\mathrm{w} / \mathrm{v})$ uranyl acetate and examined with a LEO model 912AB electron microscope. Gliding motility was observed via oil-immersion phase-contrast microscopy of the edge of colonies in exponential growth phase. The $\mathrm{pH}$ range ( $\mathrm{pH} 4.0-10.0$ at intervals of $1.0 \mathrm{pH}$ units) for growth was determined in R2A broth that was buffered with citrate/phosphate buffer or Tris/hydrochloride buffer (Breznak \& Costilow, 1994). Growth at 0,1,1.5, 2, 3 and $5 \% \mathrm{NaCl}(\mathrm{w} / \mathrm{v})$ was investigated in $\mathrm{R} 2 \mathrm{~A}$ broth. Growth at various temperatures $\left(5-45^{\circ} \mathrm{C}\right)$ was determined on $\mathrm{R} 2 \mathrm{~A}$ agar. Tests in the commercial systems API ZYM, API 20E, API 20NE and API ID 32 GN (bioMérieux) were generally performed according to the manufacturer's instructions. The API ZYM test strip was read after $4 \mathrm{~h}$ incubation at $37{ }^{\circ} \mathrm{C}$, the API 20E test strip was read after 7 days, and the other API strips were examined after 4 days at $28{ }^{\circ} \mathrm{C}$.

Strain R2A36-4 ${ }^{\mathrm{T}}$ grew well on R2A medium and weakly on nutrient agar (Difco), but did not grow on trypticase soy agar or MacConkey agar (Difco). Cells were aerobic, Gramnegative, non-flagellated, gliding and rod-shaped, 0.5-
$0.6 \mu \mathrm{m}$ wide and $1.3-30 \mu \mathrm{m}$ long (Supplementary Fig. S1, available in IJSEM Online). Colonies were light yellow and irregular. Phenotypic data among strain $\mathrm{R} 2 \mathrm{~A} 36-4^{\mathrm{T}},[F$. canadensis CIP $104802^{\mathrm{T}}$ and related taxa are compared in Tables 1 and 2. Strain R2A36- $4^{\mathrm{T}}$ and $[F$.] canadensis CIP $104802^{\mathrm{T}}$ differed from most of their close relatives by their inability to grow in concentrations of $\mathrm{NaCl}$ greater than $1 \%$, and to hydrolyse aesculin (Table 1). Strain R2A36-4 could be differentiated from [F.] canadensis CIP $104802^{\mathrm{T}}$ on the basis of several properties, including colony colour, anaerobic growth, glucose fermentation, nitrate reduction and indole production (Table 2).

Fatty acid methyl esters were extracted and prepared by using the standard protocol of the Microbial Identification system (MIDI; Microbial ID) from cells grown on R2A for $24 \mathrm{~h}$ at $28{ }^{\circ} \mathrm{C}$. Isoprenoid quinones were analysed by HPLC as described by Groth et al. (1996). The DNA G+C content was determined by HPLC analysis of deoxyribonucleosides as described by Mesbah et al. (1989) using a reversed-phase column (Supelcosil LC-18 S; Supelco). The

Table 1. Differential phenotypic characteristics among Solitalea gen. nov. and related genera of the family Sphingobacteriaceae

Taxa: 1, Solitalea gen. nov.; 2, Mucilaginibacter (data from Pankratov et al., 2007); 3, Nubsella zeaxanthinifaciens TDMA- $5^{\mathrm{T}}$ (Asker et al., 2008); 4, Olivibacter (4 species) (Ntougias et al., 2007; Wang et al., 2008); 5, Parapedobacter (2 species) (Kim et al., 2007, 2008); 6, Pedobacter (20 species) (Baik et al., 2007; Hwang et al., 2006; Gallego et al., 2006; Kwon et al., 2007; Muurholm et al., 2007; Shivaji et al., 2005; Steyn et al., 1998; Ten et al., 2006b; Vanparys et al., 2005; Yoon et al., 2006, 2007a, b, c, d); 7, Sphingobacterium (7 species) (Kim et al., 2006; Shivaji et al., 1992; Steyn et al., 1998; Takeuchi \& Yokota, 1992). +, Positive; -, negative; v, variable; ND, no data available.

\begin{tabular}{|c|c|c|c|c|c|c|c|}
\hline Characteristic & 1 & 2 & 3 & 4 & 5 & 6 & 7 \\
\hline Relation to oxygen & $\mathrm{v}$ & $\begin{array}{c}\text { Facultatively } \\
\text { anaerobic }\end{array}$ & $\begin{array}{l}\text { Strictly } \\
\text { aerobic }\end{array}$ & $\begin{array}{l}\text { Strictly } \\
\text { aerobic }\end{array}$ & $\begin{array}{l}\text { Strictly } \\
\text { aerobic }\end{array}$ & $\begin{array}{l}\text { Strictly } \\
\text { aerobic }\end{array}$ & $\begin{array}{c}\text { Facultatively } \\
\text { anaerobic }\end{array}$ \\
\hline \multicolumn{8}{|l|}{ Growth at: } \\
\hline $5{ }^{\circ} \mathrm{C}$ & - & + & - & $\mathrm{V}$ & - & $+^{*}$ & $\mathrm{~V}$ \\
\hline $40{ }^{\circ} \mathrm{C}$ & $\mathrm{V}$ & - & + & $\mathrm{v}$ & $\mathrm{V}$ & - & $\mathrm{V}$ \\
\hline Growth at $>1 \% \mathrm{NaCl}$ & - & - & ND & + & $+\dagger$ & + & + \\
\hline Glucose fermentation & $\mathrm{V}$ & + & - & $+\ddagger$ & $+\dagger$ & $\mathrm{V}$ & + \\
\hline Nitrate reduction & $\mathrm{v}$ & ND & - & ND & - & - & $\mathrm{V}$ \\
\hline Arginine dihydrolase & - & $\mathrm{ND}$ & - & $+\ddagger$ & - & $\mathrm{V}^{*}$ & ND \\
\hline \multicolumn{8}{|l|}{ Hydrolysis of: } \\
\hline DNA & $\mathrm{V}$ & ND & + & ND & ND & $\mathrm{V}$ & $\mathrm{V}$ \\
\hline Gelatin & + & $\mathrm{ND}$ & + & $+\ddagger$ & - & $\mathrm{v}$ & $\mathrm{V}$ \\
\hline Starch & + & + & + & $-\S$ & ND & $\mathrm{v}$ & $\mathrm{v}$ \\
\hline Aesculin & -11 & - & + & $+末$ & $+\dagger$ & $\mathrm{v}$ & $\mathrm{v}$ \\
\hline Urea & - & ND & - & $+\ddagger$ & - & - & $\mathrm{v}$ \\
\hline \multicolumn{8}{|l|}{ Assimilation of: } \\
\hline Arabinose & $\mathrm{V}$ & $\mathrm{V}$ & - & $+\ddagger$ & $\mathrm{V}$ & $\mathrm{v}$ & $\mathrm{v}$ \\
\hline Mannitol & - & - & - & $\mathrm{V}$ & + & $\mathrm{v}$ & $\mathrm{v}$ \\
\hline Maltose & + & + & + & $\mathrm{V}$ & + & $\mathrm{V}$ & + \\
\hline Malate & - & - & + & $-\ddagger$ & - & - & - \\
\hline DNA G $+C$ content $(\mathrm{mol} \%)$ & $37-38.1$ & $42-46$ & 38.6 & $39.2-45.6$ & $45.6-50.1$ & $36.9-44.2$ & $37.7-44.2$ \\
\hline
\end{tabular}

${ }^{*}$ No data available for Pedobacter caeni, Pedobacter africanus or Pedobacter saltans

$\dagger$ Data only for Parapedobacter koreensis.

$\ddagger$ Data only for three species, Olivibacter soli, Olivibacter ginsengisoli and Olivibacter terrae.

$\$$ Data only for Olivibacter sitiensis.

IIData only for strain R2A36-4 ${ }^{\mathrm{T}}$. 
Table 2. Phenotypic comparison between strain $R 2 A 36-4^{\top}$ and $[F$.$] canadensis CIP 104802^{\top}$

Both strains are positive for catalase, oxidase, Voges-Proskauer reaction, hydrolysis of starch and gelatin, and alkaline phosphatase, esterase (C4), esterase lipase (C8), leucine arylamidase, valine arylamidase, cystine arylamidase, acid phosphatase, naphthol-AS-BIphosphohydrolase, $\alpha$-galactosidase, $\beta$-galactosidase, $N$-acetyl- $\beta$-glucosaminidase and $\alpha$-fucosidase, but negative for CM-cellulose hydrolysis, arginine dihydrolase, urease, lysine decarboxylase, ornithine decarboxylase, citrate utilization, $\mathrm{H}_{2} \mathrm{~S}$ production, tryptophan deaminase, lipase (C14), $\beta$-glucuronidase and $\alpha$-mannosidase. Both strains assimilate D-glucose, maltose, D-mannose and salicin, but do not assimilate D-mannitol, potassium gluconate, capric acid, adipic acid, malic acid, trisodium citrate, phenylacetic acid, Lrhamnose, D-ribose, inositol, sucrose, itaconic acid, suberic acid, sodium malonate, sodium acetate, lactic acid, potassium 5-ketogluconate, 3-hydroxybenzoic acid, D-sorbitol, propionic acid, valeric acid, L-histidine, potassium 2-ketogluconate, 3-hydroxybutyric acid and 4-hydroxybenzoic acid. +, Positive; -, negative.

\begin{tabular}{|c|c|c|}
\hline Characteristic & Strain R2A36-4 & CIP $104802^{\mathrm{T}}$ \\
\hline Colony colour & Light yellow & White \\
\hline Anaerobic growth & - & $+^{*}$ \\
\hline Glucose fermentation & - & + \\
\hline $\mathrm{pH}$ range for growth & $5-8$ & $5-10^{*}$ \\
\hline Nitrate reduction & - & $+^{*}$ \\
\hline Indole production & - & $+^{*}$ \\
\hline \multicolumn{3}{|l|}{ Hydrolysis of: } \\
\hline Aesculin & - & + \\
\hline Casein & - & $+^{*}$ \\
\hline DNA & - & $+^{*}$ \\
\hline \multicolumn{3}{|l|}{ Assimilation of: } \\
\hline L-Arabinose & - & + \\
\hline$N$-Acetylglucosamine & + & - \\
\hline L-Alanine & - & + \\
\hline Glycogen & - & + \\
\hline L-Serine & - & + \\
\hline Melibiose & - & + \\
\hline L-Fucose & - & - \\
\hline L-Proline & - & + \\
\hline \multicolumn{3}{|l|}{ Enzymic activities } \\
\hline Trypsin & - & + \\
\hline$\alpha$-Chymotrypsin & - & + \\
\hline$\alpha$-Glucosidase & - & + \\
\hline$\beta$-Glucosidase & - & + \\
\hline DNA G $+\mathrm{C}$ content $(\mathrm{mol} \%)$ & 38.1 & 37 \\
\hline
\end{tabular}

${ }^{\star}$ Data from Christensen (1980).

DNA G + C content of strain $\mathrm{R} 2 \mathrm{~A} 36-4^{\mathrm{T}}$ was $38.1 \%$. The major respiratory quinone of strain $\mathrm{R} 2 \mathrm{~A} 36-4^{\mathrm{T}}$ was MK-7. The major fatty acids of strains $\mathrm{R} 2 \mathrm{~A} 36-4^{\mathrm{T}}$ and $[F$. canadensis CIP $104802^{\mathrm{T}}$ were iso- $\mathrm{C}_{15: 0}(33.3-36.2 \%)$, iso- $\mathrm{C}_{17: 0} 3-\mathrm{OH}(9.8-13.0 \%$ ), summed feature 3 (comprising $\mathrm{C}_{16: 1} \omega 7 c$ and/or iso- $\left.\mathrm{C}_{15: 0} 2-\mathrm{OH} ; 9.2-10.2 \%\right)$ and $\mathrm{C}_{15: 1} \omega 6 c(5.2-7.4 \%)$ (Table 3$)$. The two strains could be distinguished from the other taxa studied by means of the presence of $\mathrm{C}_{17: 1} \omega 6 c$, a lower amount of summed feature 3 and a higher amount of $\mathrm{C}_{15: 1} \omega 6 \mathrm{c}$ as compared with closely related genera. The differences in the fatty acid compositions of strain R2A36-4 $4^{\mathrm{T}}$ and $\left[F\right.$.] canadensis CIP $104802^{\mathrm{T}}$ were also notable (see Supplementary Table S1, in IJSEM Online).

The 16S rRNA gene sequence was determined by PCR amplification (Kwon et al., 2003) and direct sequencing (Hiraishi, 1992). By using the EzTaxon server (http:// www.eztaxon.org/; Chun et al., 2007) the novel isolate was shown to be closely related to [F.] canadensis CIP $104802^{\mathrm{T}}$. The 16S rRNA gene sequences retrieved were aligned with that of the novel strain (approximately 1440 bases), using the program MEGALINGN (DNASTAR). Strain R2A36-4 $4^{\mathrm{T}}$ showed the highest sequence similarity $(93.2 \%)$ to $[F$.] canadensis CIP $104802^{\mathrm{T}}$ (GenBank accession no. AB078046). The sequence similarities among the type strains of all other species studied were less than $90 \%$. Phylogenetic and molecular evolutionary analyses were conducted using MEGA version 3.0 (Kumar et al., 2004), clustering was determined using the neighbour-joining and maximum-parsimony algorithms and bootstrap analysis (1000 replications) was performed to determine the stability of the clusters. The neighbour-joining tree is shown in Fig. 1. A similar result (not shown) was obtained using the maximum-parsimony algorithm. The novel isolate formed a cluster with $[F$.] canadensis CIP $104802^{\mathrm{T}}$ with $100 \%$ bootstrap support. This cluster was grouped into another larger compact cluster (100\% bootstrap value support) that was composed of the genera Pedobacter, Parapedobacter, Nubsella, Mucilaginibacter, Sphingobacterium and Olivibacter. However, strain R2A36-4 ${ }^{\mathrm{T}}$ and [F.] canadensis CIP $104802^{\mathrm{T}}$ were clearly separated from the type species of the genus Flexibacter, Flexibacter flexilis NBRC $15060^{\mathrm{T}}$. From the phylogenetic tree (Fig. 1), it is clear that the novel isolate and [F.] canadensis CIP $104802^{\mathrm{T}}$ should be affiliated with the family Sphingobacteriaceae, not the family Flexibacteraceae. However, the cluster including strain $\mathrm{R} 2 \mathrm{~A} 36-4^{\mathrm{T}}$ and $[F$.] canadensis CIP $104802^{\mathrm{T}}$ was distinct from taxa with validly published names. Their unique phylogenetic position and low sequence similarity level with respect to other recognized bacterial species studied demonstrates that the two strains represent a novel genus. Therefore, we propose that strain R2A36- $4^{\mathrm{T}}$ should be considered to represent a novel species within a new genus, for which the name Solitalea koreensis gen. nov., sp. nov. is proposed. It is also proposed that $[F$. canadensis be transferred to this genus as Solitalea canadensis comb. nov.

\section{Description of Solitalea gen. nov.}

Solitalea (So.li.ta'le.a. L. n. solum soil; L. fem. n. talea a rod; N.L. fem. n. Solitalea a rod isolated from soil).

Cells are non-flagellated rods or elongated rods and motile by gliding, Gram-negative and obligately aerobic or facultative anaerobic. No spores are formed. Mesophilic and non-halotolerant. Catalase- and oxidase-positive. 
Table 3. Cellular fatty acid compositions of Solitalea gen. nov. and related genera of the family Sphingobacteriaceae

Genera: 1, Solitalea gen. nov. 2, Mucilaginibacter (2 species) (date from Pankratov et al., 2007); 3, Nubsella (Asker et al., 2008); 4, Olivibacter (4 species) (Ntougias et al., 2007; Wang et al., 2008); 5, Parapedobacter (2 species) (Kim et al., 2007, 2008); 6, Pedobacter (20 species) (Baik et al., 2007; Hwang et al., 2006; Gallego et al., 2006; Kwon et al., 2007; Muurholm et al., 2007; Shivaji et al., 2005; Steyn et al., 1998; Ten et al., 2006b; Vanparys et al., 2005; Yoon et al., 2006, 2007a, b, c, d); 7, Sphingobacterium (11 species) (Liu et al., 2008; Mehnaz et al., 2007; Steyn et al., 1998; Ten et al., 2006a; Yoo et al., 2007). Values are percentages of total fatty acids. tr, Less than $1 \%$ of the total fatty acids.

\begin{tabular}{|c|c|c|c|c|c|c|c|}
\hline Fatty acid & 1 & 2 & 3 & 4 & 5 & 6 & 7 \\
\hline anteiso- $\mathrm{C}_{13: 0}$ & $\operatorname{tr}$ & $\operatorname{tr}$ & $\operatorname{tr}$ & $\operatorname{tr}$ & tr to 11.4 & $\operatorname{tr}$ & $\operatorname{tr}$ \\
\hline iso- $\mathrm{C}_{13: 0}$ & tr to 2.5 & $\operatorname{tr}$ & $\operatorname{tr}$ & $\operatorname{tr}$ & $\operatorname{tr}$ & $\operatorname{tr}$ & $\operatorname{tr}$ \\
\hline $\mathrm{C}_{14: 0}$ & $\operatorname{tr}$ & $\operatorname{tr}$ & $\operatorname{tr}$ & tr to 2.0 & tr to 1.1 & tr to 2.5 & tr to 3.9 \\
\hline iso- $\mathrm{C}_{14: 0}$ & tr to 1.8 & $\operatorname{tr}$ & $\operatorname{tr}$ & $\operatorname{tr}$ & $\operatorname{tr}$ & $\operatorname{tr}$ & $\operatorname{tr}$ \\
\hline $\mathrm{C}_{15: 0}$ & $\operatorname{tr}$ & $3.2-4.5$ & 3.9 & $\operatorname{tr}$ & $\operatorname{tr}$ & tr to 4.2 & $\operatorname{tr}$ \\
\hline $\mathrm{C}_{15: 0} 2-\mathrm{OH}$ & $\operatorname{tr}$ & $\operatorname{tr}$ & 1.0 & $\operatorname{tr}$ & $\operatorname{tr}$ & tr to 1.5 & $\operatorname{tr}$ \\
\hline $\mathrm{C}_{15: 0} 3-\mathrm{OH}$ & tr to 2.1 & $\operatorname{tr}$ & 1.3 & $\operatorname{tr}$ & tr to 1.7 & $\operatorname{tr}$ & $\operatorname{tr}$ \\
\hline anteiso- $\mathrm{C}_{15: 0}$ & $2.0-7.7$ & $\operatorname{tr}$ & 2.3 & $\operatorname{tr}$ & $\operatorname{tr}$ & tr to 3.9 & tr to 4.1 \\
\hline iso- $\mathrm{C}_{15: 0}$ & $33.3-36.2$ & $15.7-32.2$ & 29.4 & $29.3-35.9$ & $29.3-33.6$ & $15-44.7$ & $17.7-45.6$ \\
\hline iso- $\mathrm{C}_{15: 0} 3-\mathrm{OH}$ & $3.3-3.5$ & $1.8-3.2$ & 3.2 & $1.9-3.3$ & $2.3-3.7$ & $1.5-4.1$ & $1.3-4.3$ \\
\hline $\mathrm{C}_{15: 1} \omega 6 c$ & $5.2-7.4$ & tr to 1.2 & 3.6 & $\operatorname{tr}$ & tr to 1.1 & tr to 5.8 & $\operatorname{tr}$ \\
\hline anteiso- $\mathrm{C}_{15: 1}$ & $\operatorname{tr}$ & $5.8-21.2$ & $\operatorname{tr}$ & tr to 1.1 & tr & tr & $\operatorname{tr}$ \\
\hline iso- $\mathrm{C}_{15: 1} \mathrm{G}$ & $\operatorname{tr}$ & $\operatorname{tr}$ & $\operatorname{tr}$ & $\operatorname{tr}$ & $\operatorname{tr}$ & $\operatorname{tr}$ & tr to 1.8 \\
\hline $\mathrm{C}_{16: 0}$ & $1.7-2.4$ & tr to 3.1 & $\operatorname{tr}$ & $5.5-10.4$ & $2.7-6.0$ & tr to 15.5 & $2.1-10.9$ \\
\hline $\mathrm{C}_{16: 0} 2-\mathrm{OH}$ & $\operatorname{tr}$ & $\operatorname{tr}$ & $\operatorname{tr}$ & tr to 2.6 & tr to 1.1 & $\operatorname{tr}$ & $\operatorname{tr}$ to 3.2 \\
\hline $\mathrm{C}_{16: 0} 3-\mathrm{OH}$ & tr to 1.5 & $\operatorname{tr}$ & $\operatorname{tr}$ & tr to 2.0 & $1.9-2.3$ & tr to 4.5 & tr to 6.4 \\
\hline iso- $\mathrm{C}_{16: 0}$ & $2.3-3.1$ & tr to 1.5 & $\operatorname{tr}$ & $\operatorname{tr}$ & $\operatorname{tr}$ & tr to 2.0 & $\operatorname{tr}$ to 2.3 \\
\hline iso- $\mathrm{C}_{16: 0} 3-\mathrm{OH}$ & tr to 1.0 & $\operatorname{tr}$ & 1.4 & $\operatorname{tr}$ & $\operatorname{tr}$ & tr to 3.1 & tr to 1.6 \\
\hline $\mathrm{C}_{16: 0} \quad 10$-methyl & $\operatorname{tr}$ & $\operatorname{tr}$ & $\operatorname{tr}$ & $\operatorname{tr}$ & tr to 7.1 & $\operatorname{tr}$ & tr to 9.7 \\
\hline iso- $\mathrm{C}_{16: 1} \mathrm{H}$ & $1.0-1.1$ & $\operatorname{tr}$ & $\operatorname{tr}$ & $\operatorname{tr}$ & $\operatorname{tr}$ & tr to 2.5 & tr to 1.0 \\
\hline $\mathrm{C}_{16: 1} \omega 5 c$ & $1.6-3.5$ & $2.6-5.8$ & $\operatorname{tr}$ & tr to 1.3 & $\operatorname{tr}$ & tr to 4.7 & tr to 1.5 \\
\hline $\mathrm{C}_{17: 0} 2-\mathrm{OH}$ & $\operatorname{tr}$ & $\operatorname{tr}$ & $\operatorname{tr}$ & $\operatorname{tr}$ & $\operatorname{tr}$ & tr to 8.9 & tr to 2.4 \\
\hline iso- $\mathrm{C}_{17: 0}$ & tr to 1.4 & $\operatorname{tr}$ & $\operatorname{tr}$ & $\operatorname{tr}$ & $\operatorname{tr}$ & tr to 1.8 & $\operatorname{tr}$ \\
\hline anteiso- $\mathrm{C}_{17: 0}$ & $\operatorname{tr}$ & tr to 4.5 & $\operatorname{tr}$ & $\operatorname{tr}$ & tr to 3.1 & $\operatorname{tr}$ & $\operatorname{tr}$ \\
\hline iso- $\mathrm{C}_{17: 0} 3-\mathrm{OH}$ & $9.8-13.0$ & $8.9-13.1$ & 15.9 & $11.2-12.4$ & $14.4-16.3$ & $6.0-20.4$ & $5.9-19.7$ \\
\hline $\mathrm{C}_{17: 1} \omega 6 c$ & $1.0-2.4$ & $\operatorname{tr}$ & $\operatorname{tr}$ & $\operatorname{tr}$ & $\operatorname{tr}$ & tr & $\operatorname{tr}$ \\
\hline $\mathrm{C}_{17: 1} \omega 8 c$ & tr to 1.2 & tr to 1.5 & 1.2 & $\operatorname{tr}$ & $\operatorname{tr}$ & tr to 1.1 & $\operatorname{tr}$ \\
\hline iso- $\mathrm{C}_{17: 1} \omega 9 c$ & $1.8-5.9$ & $\operatorname{tr}$ to 2.7 & 5.1 & $\operatorname{tr}$ to 2.0 & $\operatorname{tr}$ to 7.1 & $1.6-7.6$ & $\operatorname{tr}$ to 3.5 \\
\hline anteiso- $\mathrm{C}_{17: 1} \omega 9 c$ & $\operatorname{tr}$ & $\operatorname{tr}$ & $\operatorname{tr}$ & $\operatorname{tr}$ & $\operatorname{tr}$ & tr to 4.7 & $\operatorname{tr}$ \\
\hline $\mathrm{C}_{18: 0}$ & $\operatorname{tr}$ & $\operatorname{tr}$ & $\operatorname{tr}$ & tr to 1.5 & tr to 1.2 & $\operatorname{tr}$ & tr to 1.2 \\
\hline $\mathrm{C}_{18: 1} \omega 5 c$ & $\operatorname{tr}$ & $\operatorname{tr}$ & $\operatorname{tr}$ & $\operatorname{tr}$ & $\operatorname{tr}$ & tr to 1.2 & $\operatorname{tr}$ \\
\hline $\mathrm{C}_{18: 1} \omega 7 c$ & $\operatorname{tr}$ & $\operatorname{tr}$ & $\operatorname{tr}$ & $\operatorname{tr}$ & $\operatorname{tr}$ & $\operatorname{tr}$ & tr to 1.0 \\
\hline Unknown 13.565 & $1.1-3.5$ & $\operatorname{tr}$ & 3.1 & $\operatorname{tr}$ & $\operatorname{tr}$ & tr to 5.0 & tr to 1.4 \\
\hline Unknown 13.961 & $\operatorname{tr}$ & $\operatorname{tr}$ & $\operatorname{tr}$ & tr to 2.1 & $\operatorname{tr}$ & tr to 1.4 & $\operatorname{tr}$ \\
\hline Unknown 14.959 & $\operatorname{tr}$ & $\operatorname{tr}$ & $\operatorname{tr}$ & $\operatorname{tr}$ & $\operatorname{tr}$ & tr to 1.5 & $\operatorname{tr}$ \\
\hline Unknown 16.582 & $\operatorname{tr}$ & $\operatorname{tr}$ & 1.4 & tr to 1.1 & tr to 1.1 & tr to 1.7 & $\operatorname{tr}$ \\
\hline \multicolumn{8}{|l|}{ Summed features* } \\
\hline 1 & tr to 1.2 & $\operatorname{tr}$ & $\operatorname{tr}$ & $\operatorname{tr}$ & $\operatorname{tr}$ & $\operatorname{tr}$ & $\operatorname{tr}$ \\
\hline 3 & $9.2-10.2$ & $21.5-24.7$ & 20.1 & $31.6-43.2$ & $19.4-27.8$ & $8.0-48$ & $14.9-56.0$ \\
\hline 4 & tr to 1.5 & $\operatorname{tr}$ & $\operatorname{tr}$ & $\operatorname{tr}$ & $\operatorname{tr}$ & tr to 1.7 & $\operatorname{tr}$ \\
\hline 5 & $\operatorname{tr}$ & $\operatorname{tr}$ & $\operatorname{tr}$ & $\operatorname{tr}$ & $\operatorname{tr}$ & $\operatorname{tr}$ & tr to 1.1 \\
\hline 6 & $\operatorname{tr}$ & $\operatorname{tr}$ & $\operatorname{tr}$ & $\operatorname{tr}$ & $\operatorname{tr}$ to 1.2 & $\operatorname{tr}$ & $\operatorname{tr}$ \\
\hline
\end{tabular}

${ }^{\star}$ Summed feature 1 comprises $\mathrm{C}_{13: 0} 3-\mathrm{OH}$ and/or iso- $\mathrm{C}_{15: 1} \mathrm{I} / \mathrm{H}$; summed feature 3 comprises $\mathrm{C}_{16: 1} \omega 7 c$ and/or iso- $\mathrm{C}_{15: 0} 2-\mathrm{OH}$; summed feature 4 comprises iso- $\mathrm{C}_{17: 1} \mathrm{I}$ and/or anteiso- $\mathrm{C}_{17: 1} \mathrm{~B}$; summed feature 5 comprises $\mathrm{C}_{16: 0}$ 10-methyl and/or iso- $\mathrm{C}_{17: 1} \omega 9 c$; summed feature 6 comprises $\mathrm{C}_{19: 1} \omega 11 c$ and/or unknown 18.756 . 


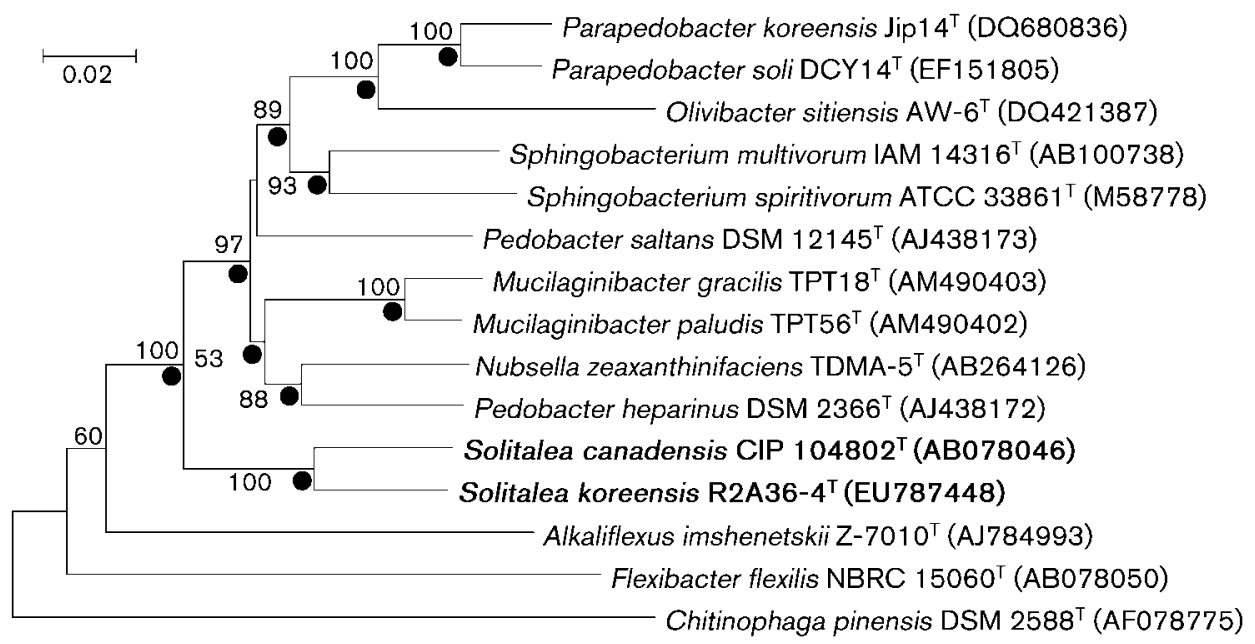

Fig. 1. Neighbour-joining tree based on $16 \mathrm{~S}$ rRNA gene sequences showing the phylogenetic position of strain $R 2 A 34-6^{\top}$. Numbers at nodes indicate percentages based on 1000 bootstrap resamplings. Filled circles indicate that the corresponding branches were also recovered in the maximum-parsimony tree. Bar, 0.02 substitutions per nucleotide position.

Major respiratory quinone is MK-7. The $\mathrm{G}+\mathrm{C}$ contents of the genomic DNA are 37.0-38.1 mol\%. Phylogenetically, the genus is affiliated to the family Sphingobacteriaceae. The type species is Solitalea koreensis sp. nov.

\section{Description of Solitalea koreensis sp. nov.}

Solitalea koreensis (ko.re.en'sis. N.L. fem. adj. koreensis pertaining to Korea, from where the organism was isolated).

Exhibits the following properties in addition to those given in the genus description. Cells are $0.5-0.6 \mu \mathrm{m}$ wide and 1.3-30 $\mu \mathrm{m}$ long. Colonies are light yellow and irregular. Grows at $10-35{ }^{\circ} \mathrm{C}$, in the presence of $0-1 \%(w / v) ~ \mathrm{NaCl}$ and at $\mathrm{pH} 5-8$. Optimum growth occurs at $28-30{ }^{\circ} \mathrm{C}$ and $\mathrm{pH}$ 6.0-7.0. Hydrolyses starch and tyrosine. Does not hydrolyse casein, CM-cellulose or DNA. Positive for gelatin hydrolysis, $\beta$-galactosidase and Voges-Proskauer test. Negative for nitrate reduction, indole production, glucose fermentation, arginine dihydrolase, urease, aesculin hydrolysis, lysine decarboxylase, ornithine decarboxylase, citrate utilization, $\mathrm{H}_{2} \mathrm{~S}$ production and tryptophan deaminase (API 20NE and API 20E test strips). Assimilative reactions and enzymic activities are shown in Table 2. Predominant fatty acids are iso- $\mathrm{C}_{15: 0}$, iso- $\mathrm{C}_{17: 0} 3-\mathrm{OH}$, summed feature 3 and $\mathrm{C}_{15: 1} \omega 6 c$. The DNA G $+\mathrm{C}$ content of the type strain is $38.1 \mathrm{~mol} \%$.

The type strain, R2A36- $4^{\mathrm{T}} \quad$ (=KACC $12953^{\mathrm{T}}=\mathrm{DSM}$ $21342^{\mathrm{T}}$ ), was isolated from a greenhouse soil sample collected from Yongin region, Republic of Korea.

\section{Description of Solitalea canadensis comb. nov.}

Solitalea canadensis (ca.na.den'sis. N.L. fem. adj. canadensis pertaining to Canada, from where the organism was isolated).
Basonym: Flexibacter canadensis Christensen 1980.

The description is identical to that given for [F.] canadensis by Christensen (1980). In addition, grows in the presence of $0-1 \%(\mathrm{w} / \mathrm{v}) \mathrm{NaCl}$. Positive for glucose fermentation, aesculin hydrolysis, gelatin hydrolysis, $\beta$-galactosidase and Voges-Proskauer test, and negative for arginine dihydrolase, urease, lysine decarboxylase, ornithine decarboxylase, citrate utilization, $\mathrm{H}_{2} \mathrm{~S}$ production and tryptophan deaminase (API 20NE and API 20E test strips). Assimilative reactions and enzymic activities are shown in Table 2. Predominant fatty acids are iso- $\mathrm{C}_{15: 0}$, summed feature 3 , iso- $\mathrm{C}_{17: 0} 3-\mathrm{OH}$, anteiso- $\mathrm{C}_{15: 0}$ and $\mathrm{C}_{15: 1} \omega 6 c$.

The type strain is UASM $9 D^{\mathrm{T}}\left(=\mathrm{ATCC} 29591^{\mathrm{T}}=\mathrm{CIP}\right.$ $104802^{\mathrm{T}}=\mathrm{DSM} \quad 3403^{\mathrm{T}}=\mathrm{NBRC} \quad 15130^{\mathrm{T}}=\mathrm{JCM} \quad 21819^{\mathrm{T}}=$ KACC $13276^{\mathrm{T}}=\operatorname{LMG} 8368^{\mathrm{T}}$ ).

\section{Acknowledgements}

We are grateful to Professor Jean Euzéby for the nomenclature. This study was supported by Biogreen 21 Program (code 20080401034028) of Rural Development Administration, Republic of Korea.

\section{References}

Asker, D., Beppu, T. \& Ueda, K. (2008). Nubsella zeaxanthinifaciens gen. nov., sp. nov., a zeaxanthin-producing bacterium of the family Sphingobacteriaceae isolated from freshwater. Int J Syst Evol Microbiol 58, 601-606.

Baik, K. S., Park, Y. D., Kim, M. S., Park, S. C., Moon, E. Y., Rhe, M. S., Choi, J. H. \& Seong, C. N. (2007). Pedobacter koreensis sp. nov., isolated from fresh water. Int J Syst Evol Microbiol 57, 20792083.

Bernardet, J.-F. \& Grimont, P. A. D. (1989). Deoxyribonucleic acid relatedness and phenotypic characterization of Flexibacter columnaris sp. nov., nom. rev., Flexibacter psychrophilus sp. nov., nom. rev., and 
Flexibacter maritimus Wakabayashi, Hikida, and Masumura 1986. Int J Syst Bacteriol 39, 346-354.

Bernardet, J.-F., Segers, P., Vancanneyt, M., Berthe, F., Kersters, K. \& Vandamme, P. (1996). Cutting a Gordian knot: emended classification and description of the genus Flavobacterium, emended description of the family Flavobacteriaceae, and proposal of Flavobacterium hydatis nom. nov. (basonym, Cytophaga aquatilis Strohl and Tait 1978). Int J Syst Bacteriol 46, 128-148.

Breznak, J. A. \& Costilow, R. N. (1994). Physicochemical factors in growth. In Methods for General and Molecular Bacteriology, pp. 137154. Edited by P. Gerhardt, R. G. E. Murray, W. A. Wood \& N. R. Krieg. Washington, DC: American Society for Microbiology.

Christensen, P. (1980). Flexibacter canadensis sp. nov. Int J Syst Bacteriol 30, 429-432.

Chun, J., Lee, J. H., Jung, Y., Kim, M., Kim, S., Kim, B. K. \& Lim, Y. W. (2007). EzTaxon: a web-based tool for the identification of prokaryotes based on $16 \mathrm{~S}$ ribosomal RNA gene sequences. Int J Syst Evol Microbiol 57, 2259-2261.

Fujita, T., Okamoto, M., Kosako, Y. \& Okuhara, M. (1996). Flexibacter japonensis sp. nov., a new species that produces a novel inhibitor of human leukocyte elastase isolated from soil. Curr Microbiol 33, 89-93.

Gallego, V., Garcia, M. T. \& Ventosa, A. (2006). Pedobacter aquatilis sp. nov., isolated from drinking water, and emended description of the genus Pedobacter. Int J Syst Evol Microbiol 56, 1853-1858.

Groth, I., Schumann, P., Weiss, N., Martin, K. \& Rainey, F. A. (1996). Agrococcus jenensis gen. nov., sp. nov., a new genus of actinomycetes with diaminobutyric acid in the cell wall. Int J Syst Bacteriol 46, 234 239.

Hiraishi, A. (1992). Direct automated sequencing of $16 \mathrm{~S}$ rDNA amplified by polymerase chain reaction from bacterial cultures without DNA purification. Lett Appl Microbiol 15, 210-213.

Hosoya, S. \& Yokota, A. (2007). Reclassification of Flexibacter aggregans (Lewin 1969) Leadbetter 1974 as a later heterotypic synonym of Flexithrix dorotheae Lewin 1970. Int J Syst Evol Microbiol 57, 1086-1088.

Hwang, C. Y., Choi, D. H. \& Cho, B. C. (2006). Pedobacter roseus sp. nov., isolated from a hypertrophic pond, and emended description of the genus Pedobacter. Int J Syst Evol Microbiol 56, 1831-1836.

Kämpfer, P., Young, C. C., Sridhar, K. R., Arun, A. B., Lai, W. A., Shen, F. T. \& Rekha, P. D. (2006). Transfer of [Flexibacter] sancti, [Flexibacter] filiformis, [Flexibacter] japonensis and [Cytophaga] arvensicola to the genus Chitinophaga and description of Chitinophaga skermanii sp. nov. Int J Syst Evol Microbiol 56, 2223-2228.

Kim, K. H., Ten, L. N., Liu, Q. M., Im, W. T. \& Lee, S. T. (2006). Sphingobacterium daejeonense sp. nov., isolated from a compost sample. Int J Syst Evol Microbiol 56, 2031-2036.

Kim, M. K., Na, J. R., Cho, D. H., Soung, N. K. \& Yang, D. C. (2007). Parapedobacter koreensis gen. nov., sp. nov. Int J Syst Evol Microbiol 57, 1336-1341.

Kim, M. K., Kim, Y. A., Kim, Y. J., Soung, N. K., Yi, T. H., Kim, S. Y. \& Yang, D. C. (2008). Parapedobacter soli sp. nov., isolated from soil of a ginseng field. Int J Syst Evol Microbiol 58, 337-340.

Kumar, S., Tamura, K. \& Nei, M. (2004). MEGA3: integrated software for molecular evolutionary genetics analysis and sequence alignment. Brief Bioinform 5, 150-163.

Kwon, S. W., Kim, J. S., Park, I. C., Yoon, S. H., Park, D. H., Lim, C. K. \& Go, S. J. (2003). Pseudomonas koreensis sp. nov., Pseudomonas umsongensis sp. nov. and Pseudomonas jinjuensis sp. nov., novel species from farm soils in Korea. Int J Syst Evol Microbiol 53, 21-27.

Kwon, S. W., Kim, B. Y., Lee, K. H., Jang, K. Y., Seok, S. J., Kwon, J. S., Kim, W. G. \& Weon, H. Y. (2007). Pedobacter suwonensis sp. nov., isolated from the rhizosphere of Chinese cabbage (Brassica campestris). Int J Syst Evol Microbiol 57, 480-484.

Liu, R., Liu, H., Zhang, C. X., Yang, S. Y., Liu, X. H., Zhang, K. Y. \& Lai, R. (2008). Sphingobacterium siyangense sp. nov., isolated from farm soil. Int J Syst Evol Microbiol 58, 1458-1462.

Mehnaz, S., Weselowski, B. \& Lazarovits, G. (2007). Sphingobacterium canadense sp. nov., an isolate from corn roots. Syst Appl Microbiol 30, 519-524.

Mesbah, M., Premachandran, U. \& Whitman, W. B. (1989). Precise measurement of the $\mathrm{G}+\mathrm{C}$ content of deoxyribonucleic acid by highperformance liquid chromatography. Int J Syst Bacteriol 39, 159-167.

Muurholm, S., Cousin, S., Päuker, O., Brambilla, E. \& Stackebrandt, E. (2007). Pedobacter duraquae sp. nov., Pedobacter westerhofensis sp. nov., Pedobacter metabolipauper sp. nov., Pedobacter hartonius sp. nov. and Pedobacter steynii sp. nov., isolated from a hard-water rivulet. Int J Syst Evol Microbiol 57, 2221-2227.

Nedashkovskaya, O. I., Suzuki, M., Vysotskii, M. V. \& Mikhailov, V. V. (2003). Reichenbachia agariperforans gen. nov., sp. nov., a novel marine bacterium in the Cytophaga-Flavobacterium-Bacteroides phylum. Int J Syst Evol Microbiol 53, 81-85.

Ntougias, S., Fasseas, C. \& Zervakis, G. I. (2007). Olivibacter sitiensis gen. nov., sp. nov., isolated from alkaline olive-oil mill wastes in the region of Sitia, Crete. Int J Syst Evol Microbiol 57, 398-404.

Pankratov, T. A., Tindall, B. J., Liesack, W. \& Dedysh, S. N. (2007). Mucilaginibacter paludis gen. nov., sp. nov. and Mucilaginibacter gracilis sp. nov., pectin-, xylan- and laminarin-degrading members of the family Sphingobacteriaceae from acidic Sphagnum peat bog. Int $J$ Syst Evol Microbiol 57, 2349-2354.

Reichenbach, H. (1989). Genus Flexibacter Soriano 1945, 92, ${ }^{\mathrm{AL}}$ emend. In Bergey's Manual of Systematic Bacteriology, vol. 3, pp. 2061-2071. Edited by J. T. Staley, M. P. Bryant, N. Pfenning \& J. G. Holt. Baltimore: Williams \& Wilkins.

Shivaji, S., Ray, M. K., Rao, N. S., Saisree, L., Jagannadham, M. V., Kumar, G. S., Reddy, G. S. \& Bhargava, P. M. (1992). Sphingobacterium antarcticus sp. nov., a psychrotrophic bacterium from the soils of Schirmacher Oasis, Antarctica. Int J Syst Bacteriol 42, 102-106.

Shivaji, S., Chaturvedi, P., Reddy, G. S. N. \& Suresh, K. (2005). Pedobacter himalayensis sp. nov., from the Hamta glacier located in the Himalayan mountain ranges of India. Int J Syst Evol Microbiol 55, 1083-1088.

Smibert, R. M. \& Krieg, N. R. (1994). Phenotypic characterization. In Methods for General and Molecular Bacteriology, pp. 607-655. Edited by P. Gerhardt, R. G. E. Murray, W. A. Wood \& N. R. Krieg. Washington, DC: American Society for Microbiology.

Soriano, S. (1945). Un nuevo orden de bacterias: Flexibacteriales. Ciencia e Investigacion (Buenos Aires) 1, 92-93.

Steyn, P. L., Segers, P., Vancanneyt, M., Sandra, P., Kersters, K. \& Joubert, J. J. (1998). Classification of heparinolytic bacteria into a new genus, Pedobacter, comprising four species: Pedobacter heparinus comb. nov., Pedobacter piscium comb. nov., Pedobacter africanus sp. nov. and Pedobacter saltans sp. nov. Proposal of the family Sphingobacteriaceae. Int J Syst Bacteriol 48, 165-177.

Suzuki, M., Nakagawa, Y., Harayama, S. \& Yamamoto, S. (2001). Phylogenetic analysis and taxonomic study of marine Cytophaga-like bacteria: proposal for Tenacibaculum gen. nov. with Tenacibaculum maritimum comb. nov. and Tenacibaculum ovolyticum comb. nov., and description of Tenacibaculum mesophilum sp. nov. and Tenacibaculum amylolyticum sp. nov. Int J Syst Evol Microbiol 51, 1639-1652.

Takeuchi, M. \& Yokota, A. (1992). Proposals of Sphingobacterium faecium sp. nov., Sphingobacterium piscium sp. nov., Sphingobacterium heparinum comb. nov., Sphingobacterium thalpophilum comb. nov., 
and two genospecies of the genus Sphingobacterium and synonymy of Flavobacterium yabuuchiae and Sphingobacterium spiritivorum. J Gen Appl Microbiol 38, 465-482.

Ten, L. N., Liu, Q. M., Im, W. T., Aslam, Z. \& Lee, S. T. (2006a). Sphingobacterium composti sp. nov., a novel DNase-producing bacterium isolated from compost. J Microbiol Biotechnol 16, 17281733.

Ten, L. N., Liu, Q. M., Im, W. T., Lee, M., Yang, D. C. \& Lee, S. T. (2006b). Pedobacter ginsengisoli sp. nov., a DNase-producing bacterium isolated from soil of a ginseng field in South Korea. Int $J$ Syst Evol Microbiol 56, 2565-2570.

Vanparys, B., Heylen, K., Lebbe, L. \& De Vos, P. (2005). Pedobacter caeni sp. nov., a novel species isolated from a nitrifying inoculum. Int J Syst Evol Microbiol 55, 1315-1318.

Wang, L., Ten, L. N., Lee, H. G., Im, W. T. \& Lee, S. T. (2008). Olivibacter soli sp. nov., Olivibacter ginsengisoli $\mathrm{sp}$. nov. and Olivibacter terrae sp. nov., from soil of a ginseng field and compost in South Korea. Int J Syst Evol Microbiol 58, 1123-1127.

Weon, H. Y., Kim, B.-Y., Yoo, S.-H., Lee, S.-Y., Kwon, S.-W., Go, S.-J. \& Stackebrandt, E. (2006). Niastella koreensis gen. nov., sp. nov. and Niastella yeongjuensis sp. nov., novel members of the phylum Bacteroidetes, isolated from soil cultivated with Korean ginseng. Int J Syst Evol Microbiol 56, 1777-1782.
Xie, C.-H. \& Yokota, A. (2006). Reclassification of [Flavobacterium] ferrugineum as Terrimonas ferruginea gen. nov., comb. nov., and description of Terrimonas lutea sp. nov., isolated from soil. Int J Syst Evol Microbiol 56, 1117-1121.

Yoo, S.-H., Weon, H.-Y., Jang, H.-B., Kim, B.-Y., Kwon, S.-W., Go, S.-J. \& Stackebrandt, E. (2007). Sphingobacterium composti sp. nov., isolated from cotton-waste composts. Int J Syst Evol Microbiol 57, 1590-1593.

Yoon, J. H., Lee, M. H., Kang, S. J., Park, S. Y. \& Oh, T. K. (2006). Pedobacter sandarakinus sp. nov., isolated from soil. Int J Syst Evol Microbiol 56, 1273-1277.

Yoon, J. H., Kang, S. J. \& Oh, T. K. (2007a). Pedobacter terrae sp. nov., isolated from soil. Int J Syst Evol Microbiol 57, 2462-2466.

Yoon, J. H., Kang, S. J., Oh, H. W. \& Oh, T. K. (2007b). Pedobacter insulae sp. nov., isolated from soil. Int J Syst Evol Microbiol 57, 19992003.

Yoon, J. H., Kang, S. J., Park, S. \& Oh, T. K. (2007c). Pedobacter lentus sp. nov. and Pedobacter terricola sp. nov., isolated from soil. Int J Syst Evol Microbiol 57, 2089-2095.

Yoon, M. H., Ten, L. N., Im, W. T. \& Lee, S. T. (2007d). Pedobacter panaciterrae sp. nov., isolated from soil in South Korea. Int J Syst Evol Microbiol 57, 381-386. 